Marquette University

e-Publications@Marquette

Speech Pathology and Audiology Faculty Research

and Publications

Speech Pathology and Audiology, Department of

7-1-2011

Speech-Language Pathologists Collaborating with Head Start to Improve Children's Early Language and Literacy Skills: Efficacy and Intensity Effects

Maura Jones Moyle

Marquette University, maura.moyle@marquette.edu

Sue Berman

Marquette University

Accepted version. Perspectives on Language Learning and Education, Vol. 18, No. 2 (July 2011): 53-61. DOI. (C) 2011 American Speech-Language-Hearing Association. Used with permission. 


\title{
Speech-Language Pathologists Collaborating With Head Start To Improve Children's Early Language and Literacy Skills: Efficacy and Intensity Effects
}

By Maura Jones Moyle and S. Sue Berman

\begin{abstract}
The current study examined the efficacy of a speech-language pathologistdesigned and implemented emergent literacy program for Head Start preschoolers and the influence of intensity of intervention on children's gains. Results indicated that children who participated in the intervention program exhibited greater gains than the control group on oral language, phonological awareness, and alphabet/print knowledge. Children who received a higher dosage of intervention made greater gains on vocabulary and oral language compared to the lower intensity group. Speech-language pathologists may be valuable collaborators in promoting emergent literacy skills in atrisk children.
\end{abstract}

\section{Introduction}

Emergent literacy consists of the skills that facilitate the development of later conventional reading abilities (Whitehurst \& Lonigan, 1998). In their meta-analysis of early literacy research, the National Early Literacy Panel (2008) found several emergent literacy skills that consistently predicted later reading achievement (beyond the influences of IQ and socioeconomic status [SES]), including alphabet knowledge, phonological awareness, print awareness, and oral language. Unfortunately, children who enter school behind their peers in emergent literacy skills are unlikely to catch up and may fall further behind over time (e.g., Scarborough, 2001; Snow, Burns, \& Griffin, 1998). Moreover, children with delayed language and literacy development at kindergarten are at high risk for being referred for special education services (Whitehurst \& Lonigan, 1998; 2001). Children from low SES backgrounds are at particularly high risk for entering school with weak emergent literacy skills due to factors such as less language input from adults (Hart \& Risley, 1995) and limited access to high-quality childcare (Lee \& Burkam, 2002; Miller, 1998). As a result, effective 
emergent literacy instruction is of utmost importance for children from at-risk populations to prepare them for the academic demands of formal schooling.

Speech-language pathologists (SLPS) may be valuable collaborators in promoting emergent literacy in young children, particularly given their expertise in language development and phonological awareness. In fact, research has shown that speech-language pathologists have higher levels of knowledge and mastery of phonological awareness than elementary school teachers and even reading specialists (Carroll \& Gillon, 2009; Spencer, Schuele, Guillot, \& Lee, 2008). In 2001, the American Speech-Language-Hearing Association (ASHA) published a position statement on the roles and responsibilities of SLPs with respect to reading and writing, which stated that SLPs "play a critical and direct role in the development of literacy" for children with communication disorders. In addition, SLPs may also contribute to school-wide and community literacy efforts (ASHA, 2001).

Research on Head Start teachers' early literacy instruction and classroom practices indicates that they most often target alphabet knowledge and print awareness, while activities to promote phonological awareness skills are rarely included; moreover, teacher-led, explicit language and literacy instruction is infrequent (Hawken, Johnston, \& McDonnell, 2005; Powell, Diamond, Bojczyk, \& Gerde, 2008). Other research has shown that early childhood educators are lacking adequate knowledge of early literacy development and effective instructional methods (Crim et al., 2008; Cunningham, Zibulsky, \& Callahan, 2009). Given SLPs' expertise in language, phonological awareness, and explicit instruction, it seems that a collaboration between SLPs and Head Start could prove beneficial in supporting children's early language and literacy skills above and beyond typical classroom instruction.

Although there is widespread agreement about the importance of promoting emergent literacy skills, especially for children from at-risk backgrounds, little is known about the effects of varying degrees of intensity of intervention on children's progress. According to Ukrainetz (2006), "Intensity is the frequency of encounters a student has with the intervention experience" (p. 51). Researchers and clinicians are recognizing that increased intensity leads to more gains in targeted skills (e.g., Torgesen et al., 2001). For example, Ukrainetz (2006) recommends providing daily sessions of small 
group literature-based language intervention, 60 minutes in length, for 4- to 8-week cycles. It should not be assumed, however, that more intervention is always better. For example, the National Reading Panel (National Institute of Child Health and Human Development, 2000) found that 5-18 hours of phonemic awareness instruction produced the largest effect sizes (i.e., interventions with more or less instruction resulted in reduced efficacy). In sum, more research into the effects of varying degrees of intensity on children's progress is needed.

The purposes of the current study are

1. To examine the efficacy of an SLP-designed and implemented emergent literacy program to promote the early language and literacy skills of at-risk preschoolers above and beyond regular Head Start programming.

2. To examine the influence of intensity of intervention of children's gains.

\section{Method}

\section{Participants}

Participants included 60 preschool children ( $M_{\text {age }}=53.4$ months, $S D=5.0$, age range: 46-65 months) enrolled in Head Start classrooms located within an urban Midwestern city (see Table 1).

Table 1. Participant Characteristics and Means (Standard Deviations) of Pre-Test Scores on Standardized Measures of Cognition, Articulation, Language, and Literacy

\begin{tabular}{|c|c|c|c|c|}
\hline Variable & $\begin{array}{l}\text { Experimental Group: } \\
\text { High Intensity } \\
(\mathrm{n}=16)\end{array}$ & $\begin{array}{l}\text { Experimental Group: } \\
\text { Low Intensity } \\
(\mathrm{n}=14)\end{array}$ & $\begin{array}{c}\text { Experimental } \\
\text { Group: Total } \\
(\mathrm{n}=30)\end{array}$ & $\begin{array}{l}\text { Control Group } \\
\quad(n=30)\end{array}$ \\
\hline$C A^{a}$ & $53.9(5.9)$ & $51.2(3.8)$ & $52.6(5.2)$ & $54.1(4.9)$ \\
\hline Gender & $\begin{array}{c}44 \% \text { Male } \\
56 \% \text { Female }\end{array}$ & $\begin{array}{c}36 \% \text { Male } \\
64 \% \text { Female }\end{array}$ & $\begin{array}{c}40 \% \text { Male } \\
60 \% \text { Female }\end{array}$ & $\begin{array}{c}33 \% \text { Male } \\
67 \% \text { Female }\end{array}$ \\
\hline $\mathrm{CMMS}^{\mathrm{b}, \mathrm{d}}$ & $101.5(10.2)$ & $104.9(12.0)$ & $103.1^{*}(11.0)$ & $97.0(10.5)$ \\
\hline Arizona-3 $3^{b, e}$ & $102.0(9.1)$ & $95.4(8.9)$ & $98.9(9.5)$ & 95.8 (7.7) \\
\hline
\end{tabular}




\begin{tabular}{|l|c|c|c|c|}
\hline PPVT-3 $3^{\mathrm{c}, \mathrm{f}}$ & $47.8(15.9)$ & $43.9(7.4)$ & $46.0(12.6)$ & $42.2(12.9)$ \\
\hline CELF P-2, ${ }^{\mathrm{c}, 9}$ & $35.8(13.6)$ & $31.4(7.1)$ & $33.7(11.1)$ & $33.5(12.4)$ \\
\hline TERA-3 $^{\mathrm{c}, \mathrm{h}}$ & $13.4(7.3)$ & $11.9(4.4)$ & $12.7(6.1)$ & $12.1(6.6)$ \\
\hline PIPA $^{\mathrm{c}, \mathrm{i}}$ & $9.8(9.3)$ & $6.6(4.2)$ & $8.3(7.4)$ & $7.8(9.0)$ \\
\hline
\end{tabular}

Note: All children were African American and from low-income households.

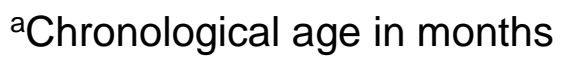

bStandard scores $($ mean $=100 ;$ standard deviation $=15$ )

'Raw scores

${ }^{d}$ Columbia Mental Maturity Scale

eArizona Articulation Proficiency Scale (3rd rev.)

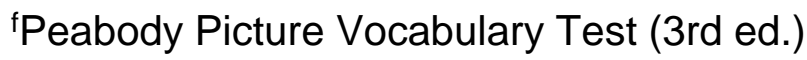

${ }^{9}$ Clinical Evaluation of Language Fundamentals Preschool (2nd ed.)

${ }^{\text {hT}}$ Test of Early Reading Ability (3rd ed.)

'Pre-Reading Inventory of Phonological Awareness

${ }^{*} p<.05$ : Experimental Group $(n=30)$ compared to Control Group $(n=30)$

All children were African American and from low-income households (per Head Start guidelines), with the majority falling below the poverty level. In addition, all participants were monolingual English speakers. Children scored within 1.5 standard deviations of the mean on the Columbia Mental Maturity Scale (CMMS; Burgemeister, Blum, \& Lorge, 1972), a measure of nonverbal cognition, and also on the Arizona Articulation Proficiency Scale, 3rd revision (Arizona-3; Fudala, 2000). Children who scored more than 1.5 standard deviations below the mean on either measure were excluded from participation. Children in the experimental and control groups were similar on all variables, except for the CMMS scores of the experimental group $(n=30)$, which were higher, on average, than the control group $(n=30), F(1,58)=4.70, p=.03$, $\eta p 2=.08$; however, the effect size was small. In addition, all of the children were considered to be typically developing by their teachers and none were receiving special services. Children were recruited from 6 classrooms located at 3 centers ( 2 classrooms at each center). All classrooms were part of the same agency and implemented The Creative Curriculum for Preschool (Dodge, Colker, \& Heroman, 2002). Data were 
collected from 2 cohorts of children over 2 consecutive years. Children in the experimental group attended a university-based preschool language and literacy program with a higher intensity of intervention in year $1(n=16)$ and a lower intensity in year 2 ( $n=14$; intensity differences explained further below). Children in the control group attended their regular Head Start programming (i.e., "business as usual"). Within the control group, 19 children participated in year 1 and 11 participated in year 2 . The research design was quasi-experimental, given that group assignment was based primarily on convenience according to each center's proximity to the university where the intervention was provided (i.e., classrooms in centers near the university were assigned to the experimental group and classrooms in distant centers were assigned to the control group). Proximity was an issue because children were transported by bus to the university in the morning for intervention and needed to return to their centers in time for lunch and naps in the afternoon. Nine (of 30) children in the control group attended classrooms that were assigned to the experimental condition but they were not able to attend the intervention program (e.g., parents consented to their children's participation in the study, but did not want them bussed to the university).

\section{Measures and Procedures}

Children were assessed in the fall and spring of the year with two language measures: Peabody Picture Vocabulary Test, 3rd Edition (PPVT-3; Dunn \& Dunn, 1997), a measure of 56 receptive vocabulary, and Clinical Fundamentals of Language Preschool, 2nd Edition (CELF P- 2; Wiig, Secord, \& Semel, 2004), an omnibus language assessment. Two measures of literacy were also administered: Test of Early Reading Ability, 3rd Edition (TERA-3; Reid, Hresko, \& Hammill, 2001), a measure of alphabet knowledge and print awareness, and the Pre-Reading Inventory of Phonological Awareness (PIPA; Dodd, Crosbie, MacIntosh, Teitzel, \& Ozanne, 2003), a measure of phonological awareness. Raw scores were used in the analyses.

\section{Intervention Program}

Children in the experimental group attended the Reading Acquisition Program (RAP), a university-based language and literacy intervention program for at-risk 
preschoolers. The goals of RAP were to promote growth in the emergent literacy skills shown to be linked to later reading achievement: vocabulary knowledge, oral language ability, alphabet knowledge, print awareness, and phonological awareness (National Early Literacy Panel, 2008). The interventions implemented in RAP were based on Justice and Pullen's (2003) recommendations of evidence-based methods for facilitating emergent literacy: adult-child shared storybook reading, teacher-directed phonological awareness curricula, and literacy-enriched play settings. Graduate students in speech language pathology, who were trained and supervised by certified SLPs (first and second authors), served as clinicians. Every session was observed by at least one of the supervising SLPs to ensure fidelity to the intervention program and students were provided with written and oral feedback. Each 2-hour and 20-minute session consisted of the following activities:

- Beginning Circle Time (20 minutes): Instruction focused on alphabet knowledge, phonics, print awareness, phonological awareness (e.g., syllable segmentation, beginning sound awareness), and preschool vocabulary/concepts (e.g., colors, shapes, spatial terms).

- Small Group Practice (80 minutes): Children were divided into four groups and rotated to different centers for 20 minutes each. The centers included (a) shared storybook reading (vocabulary, narrative structure, receptive and expressive language); (b) teacher-led phonological awareness skills and phonics; (c) Earobics (computer game for promoting phonological awareness) or journaling; and (d) print awareness and early writing.

- Snack (10 minutes): Aspects of written language awareness were infused within snack time (e.g., recipes, menus). Snack names reflected the letter/sound of the day. Conversation was encouraged.

- Literacy Enriched Play (20 minutes): The play intervention period consisted of integrating literacy props and materials into the dramatic play and art/science projects that reflected the weekly theme. Vocabulary, receptive and expressive language, and print awareness were targeted. 
- Ending Circle Time (10 minutes): Instruction focused on phonological awareness activities (e.g., syllable segmentation, rhyme awareness, beginning sound awareness).

Children in the experimental groups (i.e., Year 1 or Year 2) attended only 1 year of Intervention and were assessed in the fall and spring of the year they participated. Children in the year 1 experimental group (i.e., Experimental Group: High Intensity, $n$ 16) participated in an average of 83 hours of intervention (range: 42-98) over a 16-week period (February-May, 3 times per week). Children in the Year 2 experimental group (i.e., Experimental Group: Low Intensity, $n=14$ ) participated in an average of 81 hours of intervention (range: 51-96) over a 32-week period (October-May, two times per week). There was no difference in the average number of hours of participation between the experimental groups, $F(1,28)=.243, p=.626, n p 2=.009$; however, Year 1 children received the dosage in a shorter time period, resulting in a higher intensity of intervention.

\section{Results}

\section{Efficacy}

The first research question asked whether RAP was effective in promoting emergent literacy skills in at-risk preschoolers. We evaluated efficacy by comparing all children who attended RAP (i.e., experimental group, $n=30$ ) to children in the control group $(n=30)$. Repeated-Measures Analysis of Variance was used to examine fall to spring gains on the 4 experimental measures in terms of the main effect of time and, more important, to detect interaction effects of time $x$ group (i.e., group differences in gains over time; see Table 2).

Table 2. Efficacy Data: A Comparison of Fall to Spring Gains on Experimental Measures for Both Groups 


\begin{tabular}{|l|c|c|c|c|}
\hline & $\begin{array}{c}\text { Gain: Experimental } \\
\text { Group }(\mathrm{n}=30)\end{array}$ & $\begin{array}{c}\text { Gain: Control } \\
\text { Group }(\mathrm{n}=30)\end{array}$ & $P$ & $\eta 2$ \\
\hline PPVT-3 $^{\mathrm{a}}$ & $11.5(12.3)$ & $10.9(11.7)$ & NS & - \\
\hline CELF P-2 $^{\mathrm{a}}$ & $16.4(9.3)$ & $6.5(6.8)$ & $<.001$ & .28 \\
\hline TERA-3 $^{\mathrm{a}}$ & $7.0(5.7)$ & $3.2(4.8)$ & .007 & .12 \\
\hline PIPA $^{\mathrm{a}}$ & $15.9(11.9)$ & $7.6(8.3)$ & .003 & .15 \\
\hline
\end{tabular}

aRaw scores: Mean (standard deviation)

Main effects for time were observed for the PPVT-3: $F(1,58)=51.9, p<.001$, $\eta p 2=.47$; the CELF P-2: $F(1,58)=118.9, p<.001, \eta p 2=.67$; the TERA-3: $F(1,58)=$ $56.9, \mathrm{p}<.001, \mathrm{np} 2=.50 ;$ and the PIPA: $\mathrm{F}(1,58)=78.1, \mathrm{p}<.001, \mathrm{np} 2=.57$, demonstrating that mean scores on these measures significantly increased for children in both the experimental and control groups. In addition, significant time $x$ group interactions were observed on the CELF P-2, $F(1,58)=22.3, p<.001, \eta p 2=.28$, the TERA-3, $F(1,58)=7.7, p=.007, n p 2=.12$, and the PIPA, $F(1,58)=9.8, p=.003, n p 2=$ .15 , demonstrating that the children in the experimental group made significantly greater gains on these measures. No significant interaction was observed for the PPVT-3, $F(1,58)=.037, p=.847, n p 2=.001$.

\section{Intensity}

The second research question asked whether there were differences in gains for children in the high- versus low-intensity intervention groups. Again, Repeated measures Analysis of Variance was used to detect interaction effects of time $\mathrm{x}$ group (see Table 3).

Table 3. Intensity Data: A Comparison of Fall to Spring Gains on Experimental Measures of the Experimental Group-High Intensity versus the Experimental Group-Low Intensity 


\begin{tabular}{|l|c|c|c|c|}
\hline & $\begin{array}{c}\text { Gains: Experimental } \\
\text { Group - High Intensity } \\
(\mathrm{n}=16)\end{array}$ & $\begin{array}{c}\text { Gains: Experimental } \\
\text { Group - Low Intensity } \\
(\mathrm{n}=14)\end{array}$ & $p$ & $\eta 2$ \\
\hline PPVT-3 $^{\mathrm{a}}$ & $17.4(9.6)$ & $4.7(11.8)$ & .003 & .27 \\
\hline CELF P-2 $^{\mathrm{a}}$ & $22.2(6.8)$ & $9.7(7.0)$ & $<.001$ & .47 \\
\hline TERA-3 $^{\mathrm{a}}$ & $8.4(5.9)$ & $5.4(5.2)$ & $\mathrm{NS}$ & - \\
\hline PIPA $^{\mathrm{a}}$ & $19.3(13.5)$ & $12.0(8.7)$ & $\mathrm{NS}$ & - \\
\hline
\end{tabular}

Raw scores: Mean (standard deviation).

(Given that on average children made significant gains on all measures [see above], main effects will not be reported for this analysis.). There was a significant time $x$ group interaction on the PPVT-3, $F(1,28)=10.4, p=.003, \mathrm{np} 2=.27$, and the CELF P $2, F(1,28)=24.6, p<.001, n p 2=.47$, demonstrating that the children in the experimental group made significantly greater gains on these measures. No significant interaction effects were observed for the TERA-3, $F(1,28)=2.1, p=.160, n p 2=.07$, or the PIPA, $F(1,28)=3.0, p=.097, n p 2=.10$.

\section{Discussion}

\section{Efficacy}

Results indicated that on average all children exhibited significant gains over time; however, children in the experimental group exhibited significantly greater gains than the control group on oral language (i.e., CELF P-2), phonological awareness, and alphabet/print knowledge. Although effect sizes were small to moderate, the results are noteworthy given that on average children experienced 82 hours of RAP intervention, compared to the hundreds of hours of Head Start programming they potentially experienced during that same time period (i.e., children in the experimental group continued to attend Head Start while participating in this study). It was not surprising that RAP, designed and implemented by SLPs, had a positive and significant impact on children's language and phonological awareness skills, particularly given SLPs' 
expertise in these areas. We expected RAP to have a greater influence on vocabulary; however, the vocabulary targeted in RAP was unrelated to the vocabulary assessed by the PPVT-3. In addition, vocabulary instruction may have been a relative strength in the Head Start classrooms given that all children made progress. We were pleasantly surprised that children in the experimental group exhibited greater gains than the control group on alphabet and print awareness as measured by the TERA-3. It was the authors' experience that targeting these skills was venturing into new territory (especially compared to language and phonological awareness). Given ASHA's position statement on the roles and responsibilities of SLPs in literacy assessment and intervention (ASHA, 2001), and also considering that most SLPs work in school settings (ASHA, 2009), it is imperative that literacy become an area of emphasis across SLP training programs (e.g., Elledge et al., 2010).

\section{Intensity}

Children in the high-intensity group made greater gains on the PPVT-3 and CELF P-2 than children in the low-intensity group. Therefore, higher intensity of intervention appeared to have a greater influence on language than on alphabet/print knowledge or phonological awareness skills. Ukrainetz (2006) suggested that 40-60 minutes of phonological awareness instruction per week for 8 to 10 weeks was adequate for children to make substantial gains. While phonological awareness and alphabet/print skills are more discrete, language is complex and multidimensional; therefore, a higher intensity of intervention may be required for significant gains to be achieved.

\section{Limitations and Future Directions}

A limitation of the current study is that the influence of classroom instructional quality on children's outcomes or the actual amount of time devoted to language and literacy activities within the Head Start classrooms were not examined. As a result, we cannot rule out the possibility that children in the control group or low-intensity experimental group experienced lower quality classroom instruction and/or a reduced 
instructional emphasis on language and literacy that may have contributed to the superior results of the RAP intervention.

A fair amount of variability in children's outcomes was observed in the current study, although all children were perceived to be typically developing by their teachers. Examining child $\mathrm{x}$ instructional effects (i.e., how individual child characteristics interacted with instructional effectiveness) was beyond the scope of this study; however, more research in this area is needed. In a large scale intervention study of first-grade children's reading outcomes, Connor et al. (2009) calculated each child's recommended intervention dosage based on his or her vocabulary and word-reading skills. A computer software program (Assessment-to- Intervention, A2i) developed by Connor and colleagues used algorithms that recommended the amounts and type of instruction for individual children. Children who received the recommended dosages made more gains than those who did not. Precision of dosage was important; children who received more than the recommended dosage did not necessarily make more gains.

In sum, more research examining the effects of intensity of intervention and the needs of individual children is warranted. In addition, better assessment tools of emergent literacy that support decisions regarding intervention placement and intensity are needed. Currently, tools for monitoring children's emergent literacy skills are lacking, making it difficult to determine which children are most in need of intervention and/or not progressing as expected and, therefore, in need of program modifications (Moyle, Heilmann, \& Gorman, 2011).

\section{Clinical Implications}

Additional research investigating the best models and methods of collaboration between SLPs and early childhood educators is needed. Studies examining the effects of SLPs providing services in classrooms, co-teaching, and/or modeling lessons has shown positive effects (e.g., Korth, Sharp, \& Culatta, 2010; Roth \& Troia, 2006). Other research has examined the impact of providing professional development to Head Start teachers and other early childhood educators or day care providers, with positive results 
(e.g., Girolametto \& Weitzman, 2002; Powell, Diamond, Burchinal, \& Koehler, 2010). One of the largest efforts to improve language and literacy outcomes for low-income, at risk preschoolers has been Early Reading First (ERF). For example, in 2003, nearly 75 million dollars were awarded to $30 \mathrm{ERF}$ projects serving approximately 9,000 children (U.S. Department of Education, 2003). A large component of ERF programming is the provision of professional development to early childhood teachers in the areas of language and emergent literacy. A national evaluation of ERF, which compared projects funded in 2003 to similar non-funded projects, found that children who had participated in ERF-funded programs made significant gains in print and letter knowledge, but not in oral language or phonological awareness compared to children in the non-funded programs (Jackson et al., 2007). In contrast, children in the RAP project exhibited significant gains in oral language and phonological awareness skills compared to children in the control group; however, RAP was designed and directly implemented by SLPs and SLP graduate students, rather than early childhood/Head Start teachers. Pence, Justice, and Wiggins (2008) found that when examining early childhood educators' fidelity to a language-rich curriculum, educators were more successful in implementing activity contexts (e.g., art centers, storybook reading) than effective instructional processes (e.g., teacher-child language focused interactions). The authors suggest that, when collaborating with early childhood educators, SLPs should focus on helping teachers promote language-learning interactions instead of helping them implement specific activities. Similarly, Justice, Mashburn, Hamre, and Pianta (2008) examined the quality of language and literacy instruction in 135 publically funded preschool classrooms serving at-risk children. They found that even though most teachers exhibited high procedural fidelity to the curriculum, the quality of language and literacy instruction was low. For example, teachers were rarely observed using evidence-based strategies for facilitating language development, such as open-ended questions or modeling advanced vocabulary. It seems that providing high-quality language and literacy instruction requires a high level of expertise, even at the preschool level, and especially for children at risk. As stated by Louisa Moats (1999), "Teaching reading is rocket science." 
In summary, the expertise that SLPs possess can be a valuable asset in collaborations with Head Start and other educational agencies, especially in terms of promoting children's language and phonological awareness skills. In addition, a higher intensity of intervention may be needed to promote language gains.

\section{References}

American Speech-Language-Hearing Association. (2001). Roles and Responsibilities of Speech-Language Pathologists With Respect to Reading and Writing in Children and Adolescents [Position Statement]. Available from http://www.asha.org/policy American Speech-Language-Hearing Association. (2009). 2009 Membership Survey summary report: Number and type of responses. Rockville, MD: Author.

Burgemeister, B., Blum, L., \& Lorge, I. (1972). Columbia Mental Maturity Scale. New York, NY: Harcourt Brace Jovanovich.

Carroll, J., \& Gillon, G. (2009, November). New Zealand educators' phonological awareness knowledge. Poster presented at the annual convention of the American Speech-Language-Hearing Association, New Orleans, LA.

Connor, C. M., Piasta, S. B., Fishman, B., Glasney, S., Schatschneider, C., Crowe, E., Underwood, P., \& Morrison, F. J. (2009). Individualizing student instruction precisely: Effects of child by instruction interactions on first graders' literacy development. Child Development, 80(1), 77-100.

Crim, C., Hawkins, J., Thornton, J., Rosof, H., B., Copley, J., \& Thomas, E. (2008). Early childhood educators' knowledge of early literacy development. Issues in Teacher Education, 17(1), 17-30.

Cunningham, A. E., Zibulsky, J., \& Callahan, M. (2009). Starting small: Building preschool teacher knowledge that supports early literacy development. Special Issue on Teacher Knowledge: Reading and Writing: An Interdisciplinary Journal, 22, 487-510. 
Dodd, B., Crosbie, S., MacIntosh, B., Teitzel, T., \& Ozanne, A. (2003). Preschool and primary inventory of phonological awareness. San Antonio, TX: Psychological Corporation.

Dodge, D. T., Colker, L. J., \& Heroman, C. (2002). The creative curriculum for preschool (4th ed.). Washington, DC: Teaching Strategies, Inc.

Dunn, L. A., \& Dunn, L. M. (1997). Peabody Picture Vocabulary Test (3rd ed.). Circle Pines, MN: American Guidance Service.

Elledge, D., Hasselbeck, E., Hobek, A., Combs, S., Raisor-Becker, L., \& Creaghead, N. (2010). Perspectives on preparing graduate students to provide educationally relevant services in schools. Perspectives on School-Based Issues, 11, 40-49.

Fudala, J. B. (2000). Arizona Articulation Proficiency Scale (3rd rev.). Los Angeles, CA: Western Psychological Services.

Girolametto, L., \& Weitzman, E. (2002). Responsiveness of child care providers in interactions with toddlers and preschoolers. Language, Speech and Hearing Services in Schools, 33, 268-281.

Hart, B., \& Risley, R. T. (1995). Meaningful differences in the everyday experience of young American children. Baltimore, MD: Paul H. Brookes.

Hawken, L., Johnston, S., \& McDonnell, A. (2005). Emerging literacy views and practices of Head Start preschool teachers. Topics in Early Childhood Special Education, 25, 232-242.

Jackson, R., McCoy, A., Pistorino, C., Wilkinson, A., Burghardt, J., Clark, M., Ross, C., Schochet, P., \& Swank, P. (2007). National evaluation of early reading first: Final report. U.S. Department of Education, Institute of Education Sciences. Washington, DC: U.S. Government Printing Office.

Justice, L. M., Mashburn, A. J., Hamre, B. K., \& Pianta, R. C. (2008). Quality of language and literacy instruction in preschool classrooms serving at-risk pupils. Early Childhood Research Quarterly, 23(1), 51- 68. 
Justice, L. M., \& Pullen, P. C. (2003). Promising interventions for promoting emergent literacy skills: Three evidence-based approaches. Topics in Early Childhood Special Education, 23, 99-113.

Korth, B., Sharp, A., \& Culatta, B. (2010). Classroom-based supplemental literacy instruction: Influencing the beliefs and practices of classroom teachers. Communication Disorders Quarterly, 31, 113-127.

Lee, V. E., \& Burkam, D. T. (2002). Inequality at the starting gate: Social background differences in achievement as children begin school. Washington, DC: Economic Policy Institute.

Miller, J. E. (1998). Developmental screening scores among preschool-aged children: The roles of poverty and child health. Journal of Urban Health, 75(1), 135-152.

Moats, L. (1999). Teaching reading is rocket science: What expert teachers should be able to do. Washington, DC: American Federation of Teachers.

Moyle, M. J., Heilmann, J., Gorman, B. (2011). Tracking phonological awareness skills: A comparison of the preschool IGDIs and the PALS-PreK. Manuscript submitted for publication.

National Early Literacy Panel. (2008). Developing early literacy: Report of the National Early Literacy Panel. Washington, DC: National Institute for Literacy.

National Institute of Child Health and Human Development. (2000). Report of the National Reading Panel. Teaching children to read: An evidence-based assessment of the scientific research literature on reading and its implications for reading instruction (NIH Publication No. 00-4769). Washington, DC: U.S. Government Printing Office. Pence, K. L., Justice, L. M., \& Wiggins, A. K. (2008). Preschool teachers' fidelity in implementing a comprehensive language-rich curriculum. Language, Speech, and Hearing Services in Schools, 39, 329- 341.

Powell, D. R., Diamond, K. E., Bojczyk, K. E., \& Gerde, H. G. (2008). Head Start teachers' perspectives on early literacy. Journal of Literacy Research, 40, 422-460. 
Powell, D. R., Diamond, K. E., Burchinal, M. R., \& Koehler, M. J. (2010). Effects of an early literacy professional development intervention on Head Start teachers and children. Journal of Educational Psychology, 102(2), 299-312.

Reid, D., Hresko, W., \& Hammill, D. (2001). Test of Early Reading Ability (3rd ed.). Austin TX: PRO-ED.

Roth, F. P., \& Troia, G. A. (2006). Collaborative efforts to promote emergent literacy and efficient word recognition. Topics in Language Disorders, 26, 24-41.

Scarborough, H. S. (2001). Connecting early language and literacy to later reading (dis)abilities: Evidence, theory, and practice. In S. Neuman \& D. Dickinson (Eds.), Handbook for research in early literacy (pp. 97- 110). New York, NY: Guilford Press.

Snow, C. E., Burns, M. S., \& Griffin, P. (Eds.). (1998). Preventing reading difficulties in young children. Washington, DC: National Academy Press.

Spencer, E. J., Schuele, C. M., Guillot, K. M., \& Lee, M. W. (2008). Phonemic awareness skill of speech-language pathologists and other educators. Language, Speech, and Hearing Services in the Schools, 39, 512-520.

Torgesen, J. K., Alexander, A. W., Wagner, R. K., Rashotte, C. A., Voeller, K., \& Conway, T. (2001). Intensive remedial instruction for children with severe reading disabilities: Immediate and long-term outcomes from two instructional approaches. Journal of Learning Disabilities, 34, 33-58.

Ukrainetz, T. A. (Ed.) (2006). Contextualized language intervention: Scaffolding pre-k12 literacy achievement. Eau Claire, WI: Thinking Publications.

U.S. Department of Education. (2003). A synopsis of the 2003 Early Reading First Project grantees (CFDA Publication No. 84.359B). Washington, DC: Author.

Whitehurst, G. J., \& Lonigan, C. J. (1998). Child development and emergent literacy. Child Development, 69, 848-872. 
Whitehurst, G. J., \& Lonigan, C. J. (2001). Emergent literacy: Development from prereaders to readers. In S. B. Neuman \& D. K. Dickensen (Eds.), Handbook of early literacy research (pp. 11-29). New York, NY: Guilford Press.

Wiig, E., Secord, W., \& Semel E. (2004). Clinical evaluations of language fundamentals: Preschool ( $2^{\text {nd }}$ ed.). San Antonio, TX: Psychological Corporation. 